\title{
Business Cycles in the Maghreb : Does Trade Matter?
}

\author{
Jude Eggoh \\ Université d'Angers, Angers, France \& Université d'Abomey-Calavi, Bénin \\ Aram Belhadj \\ Université de Carthage, Nabeul, Tunisie
}

\begin{abstract}
In this paper, we test the Frankel \& Rose hypothesis of Optimum Currency Area for the Maghreb countries by demonstrating how the co-movements of outputs would respond to a trade integration process. In particular, by using panel analysis over the period 1980 2010, we evaluate if a monetary integration project across these countries is endogenous. Our main result suggests that while trade intensity may help to harmonize business cycles, the magnitude of this harmonization is lower for the Maghreb countries than for industrial countries. This result is robust even when we take into consideration many control variables including intra-industry trade, economic diversification, and financial integration. Therefore, we suggest that an acceleration of trade linkage as well as product diversification should take place prior to any move towards monetary union across the Maghreb countries.
\end{abstract}

\footnotetext{
* Corresponding Author: Jude Eggoh; Groupe de Recherche Angevin en Economie et Management (GRANEM), Université d'Angers, 13, Allée François Mitterrand, 49036, Angers Cedex 01, France; Tel: +33 648521048, E-mail: jude. eggoh@univ-angers.fr.

Co-Author: Aram Belhadj; Université de Carthage, Faculté des Sciences Economiques et de Gestion de Nabeul (FSEGN), Campus Universitaire Mrezgua, Route Hammamet, 8000, Tunisie; Tel: +216 98601751, Fax: +216 72232318, E-mail: aram.belhadj@etu.univ-orleans.fr.
}

Acknowledgements: We are grateful to S. Béji and R. Bazilier for their useful comments and suggestions. The usual disclaimer applies. 
JEL Classifications: E32, F15, F41, F43

Keywords: Business Cycles, Trade Intensity, Intra-Industry Trade, Maghreb

\section{Introduction}

The Maghreb countries have many things in common beyond mere geographical proximity. ${ }^{1}$ In particular, the five North African countries (Algeria, Libya, Mauritania, Morocco, and Tunisia) face similar economic and political challenges arising from poverty, high unemployment, and limited integration.

In recent years, the countries of this region have made important strides in the direction of future prosperity. Stability in macroeconomic conditions and some progress in economic reforms have been achieved. In addition, trade integration - either at a European level or, more recently, at Maghrebian and Arab levels - has been established.

Indeed, the creation of the Arab Maghreb Union (AMU) in 1989 aimed at coordinating economic policy among the five member states, gradually ensuring free trade among them and strengthening economic and financial linkages across all sectors in the region (Darrat and Pennathur 2002). Moreover, a number of regional initiatives have taken place in order to push trade facilitation and boost intra-regional economic integration. In this vein, the Greater Arab Free Trade Area (GAFTA), established in 1997, intended to progressively remove tariff and non-tariff barriers to intra-Arab trade (notably in manufacturing) and improve efficiency gains. Within the same context, the Agadir agreement that was signed in 2004 between Egypt, Jordan, Morocco, and Tunisia has as its main purpose the creation of a free trade area. Also, many conferences have been taking place, notably the conference on trade facilitation in Algeria, Morocco, and Tunisia that was held in Algiers in November 2005 and the Conference on the Role of the Private Sector in Economic Development and Regional Integration in the Maghreb that was held in Tunis in November 2007.

This progress towards further integration may contribute in the long run to the creation of a common market and a common currency between the countries of this

\footnotetext{
'Historically, the word Maghreb was used for the first time during the period of French colonization. It grouped Algeria, Morocco, and Tunisia. These countries belonged to what was called Djazirat al-Maghrib during the Muslim conquests. Actually, the Maghreb zone brings together Algeria, Morocco, and Tunisia (called Maghreb Central) as well as Libya and Mauritania.
} 
region. ${ }^{2}$

According to the traditional view of Optimal Currency Area (OCA), such a monetary union is beneficial if the countries involved have intensive trade relations and positive correlation of business cycles (Mundell 1961). However, following the theory of endogenous OCA (Frankel and Rose 1998), high bilateral trade increases cross-country business cycle correlation. Then, trade increase, stemming from currency union, makes this currency union optimal ex post rather than ex ante, and allows business cycle synchronization.

Based on this theory, many studies analyzed the relationship between trade and business cycle correlation in Organization for Economic Cooperation (OECD) countries (Frankel and Rose 1998, Fidrmuc 2004, Baxter and Kouparitsas 2005, Inklaar et al. 2008, Gouveia and Correia 2013, Caporale et al. 2015) as well as in Asian countries (Shin and Wang 2003, Kumakura 2006, Rana 2007), in order to discern whether these zones are optimal currency areas or not. To our knowledge, no works have dealt with this issue for the Maghreb countries. Therefore, we address the following question: how would comovements of outputs respond to this process characterized by increased interest toward developing trade flows between the Maghreb countries?

Our motivation to answer this question is strengthened by the fact that many empirical works have tested the endogeneity hypothesis of OCA for many groups of developed and developing countries but the results have been mixed. Besides, the answer to the above-mentioned question is important because the decision to join an economic and monetary union would depend on how the acceleration of trade would reduce comovement variability in these countries. The answer will then offer a vision for them as to whether the integration process will help to harmonize their economic cycles and if so, a decision to remain in the same economic and monetary area in the medium and long term would be solidly founded.

The remainder of this paper is structured as follows: Section II reviews the theoretical and empirical effect of trade on the synchronization of business cycles. It also mentions the other determinants of business cycle co-movement. Section III states the empirical methodology and data. Section IV presents the main estimation results. Finally, Section $\mathrm{V}$ concludes and offers some policy implications.

\footnotetext{
${ }^{2}$ It is useful to mention that since 2002, the creation of a single currency and a common central bank for the Maghreb has always been the main concern of the union of Maghreb banks. Moreover, during the Arab banks summit in Paris in June 2008, the project of monetary integration in the Maghreb was discussed again. In the same context, the general secretary of Arab Maghreb Union (AMU) is trying to put in place a Maghreb economic community project via detailed research done in collaboration with the African Development Bank.
} 


\section{Determinants of Business Cycle Synchronization}

According to the endogeneity theory of OCA, the foremost candidate expected to influence business cycle synchronization is trade. But, literature has identified many other potential determinants such as currency union, similarity of industrial structure, and financial integration. ${ }^{3}$

\section{A. Trade effect}

Optimum Currency Area (OCA) theory considers that countries or regions exposed to symmetric shocks or holding mechanisms for the absorption of asymmetric shocks may benefit from adopting a common currency. Mundell (1961), McKinnon (1963), and Kenen (1969) were the first to define the criteria that allow a country to benefit from belonging to a common currency area. Among the key criteria considered is the degree of trade integration between the potential members, as well as the symmetry of their business cycles. Labor mobility, fiscal transfers, financial integration, and similarity of inflation rates were also considered. ${ }^{4}$

On the contrary, the endogeneity hypothesis of OCA considers the process of monetary integration as endogenous and does not impose prerequisites. Trade integration and cycle synchronization, however, are not in fact exogenous. The underlying idea is that genuine economic integration between countries strengthens the degree of cyclical correlation and thus the advantages of adopting a single currency. The monetary integration process will then create ex-post the conditions of its success.

Frankel and Rose (1998) were the first to raise the question of the endogeneity of OCA criteria. They estimated a single-equation model based on a sample of twenty one industrialized countries from 1959 to 1993 and found a strong and robust positive relationship between bilateral trade and cycle synchronization.

Inversely, for Krugman (1993), intensified trade relations lead to a higher degree of specialization, ${ }^{5}$ because of comparative advantages issues. As a result, business cycles

\footnotetext{
${ }^{3}$ Other determinants can be stated such as factor endowments, domestic policies, and structural factors. These determinants are beyond the scope of this paper.

${ }^{4}$ For a literature review, Beine (1998).

${ }^{5}$ For Kalemli-Ozcan et al. (2001), specialization could also be a result of higher integration in both international financial and goods
} 
become more asynchronous and the relationship between bilateral trade and cycle synchronization proves to be negative.

It follows that the most determinant factor is trade specialization rather than the volume of trade. So, the underlying question is whether bilateral trade mainly occurs in similar or different sectors. If trade flows are predominantly intra-industry, i.e., trade of similar products belonging to the same industry, then we would expect the first effect to materialize, i.e., positive relationship between trade and correlation of business cycles. Inversely, if bilateral trade is, or increasingly becomes, inter-industry, i.e., trade occurring between various industries, the second prediction may hold true, i.e., negative relationship between trade and correlation of business cycles.

Subsequent studies have been conducted in order to test the relationship between trade and business synchronization, more generally for a sample of developed countries, and they have provided mixed results. Gouveia and Correia (2013) examine whether increase in trade synchronizes business cycles in the euro area from 1981 to 2011. They confirm the OCA endogeneity hypothesis while they highlight mixed results for southern European countries (Greece, Italy, Portugal, and Spain). Moreover, for the postcrisis period, 2008 2011, their results show remarkable business synchronization in the euro zone, except for Greece, Portugal, and Luxembourg, confirming the Frankel and Rose (1998) hypothesis. Inklaar et al. (2008), by using a multivariate model in order to capture the specialization and similarity of economic policy, reappraise trade and cycle synchronization linkage for 21 OECD countries over the period 1970 2003. They find that trade intensity affects business cycle synchronization, but the effect is much smaller than reported by Frankel and Rose (1998). In the same vein, Calderón et al. (2007) find from a sample of 147 countries over the period 1960 1999 that the impact of trade intensity on business cycles correlation among developing countries is positive and significant, but smaller than that reported for developed countries.

Fidrmuc (2004) re-examines the specification of Frankel and Rose for many OECD countries. His results show that intra-industry trade explains the harmonization of business cycles rather than inter-industry trade.

Also, Imbs (2004) tries to estimate for 24 developed and emerging countries, a system of simultaneous equations to disentangle the complex interactions between trade, finance, sectoral specialization, and business cycle synchronization. His results indicate that the overall effect of trade on business cycle synchronization is strong, but a sizeable 
portion is found to actually work through intra-industry trade. However, estimates of the link between inter-industry trade and cycle correlations are smaller in magnitude, and not inconsistent with existing models.

More recently, Caporale et al. (2014), by using panel data for 24 industrialized and emerging economies over the period 1988 2011, provide empirical evidence which supports the specialization paradigm for the periphery of the European Monetary Union (Greece, Ireland, Italy, Portugal, and Spain) on the one hand and confirms the endogeneity OCA hypothesis for the core of the European Monetary Union (EMU) (Austria, Belgium, Finland, France, Germany, and the Netherlands) on the other hand.

Kamakura (2006) tests the Frankel and Rose hypothesis for 13 Asia-Pacific economies using data from 1983 to 2004 and finds that, although trade appears to help account for variations in international business cycle co-movements, a more important factor is the extent to which each country specializes in the electronics industry. So, he concludes that growing trade among Asian economies is no guarantee that these countries are moving toward an OCA. The same results are found by Shin and Wang (2003) who show that intra-industry trade is the major channel by which the business cycle of Korea has become synchronized with the other Asian economies.

\section{B. Other determinants of business cycle synchronization}

The endogeneity hypothesis of OCA has been examined from another angle. In fact, many works have tried to determine the effect of monetary union on trade by resorting to the gravity model. So, in such a case, monetary union is the main determinant of the business cycle correlation of its members, via its impact on trade.

Rose (2000) tries to test the relationship between monetary union and international trade for 210 developed and developing countries over the period 1960 1996. He finds that bilateral trade between members of a monetary union is three times that of countries which preserve their own currencies. Also, Baldwin (2005) presents an analysis which measures the effects of the launching of the euro on trade. He finds that the creation of the EMU increases trade from $70 \%$ to $112 \%$, while this effect varies from $21 \%$ to $108 \%$ by considering a sectoral analysis.

Similarly, for Africa, a few works have tested the endogeneity hypothesis by measuring the effect of the creation of monetary union on trade. For example, Nitsch (2002) uses the gravity model to test the effect of the creation of the CFA franc zone (as well as the 
East Caribbean Currency Union) on trade and finds that a monetary union increases trade by almost 55\% (while the effect is negligible in the east Caribbean area). Also, Masson and Patillo (2004) use the gravity model for African countries and conclude that the effect on trade is the same as found in Rose (2000): a monetary union triples trade. Finally, the same result was also found in Carrère (2004) by resorting to the gravity model in order to examine the effect on bilateral trade of two African monetary unions (WAEMU and ECCAS). ${ }^{6}$ In the same vein, Bangaké and Eggoh (2009) argue that the existing currency unions in the CFA zone significantly enhances trade between members. However, according to their findings, the Rose effect is more substantial in the WAEMU than in ECCAS.

Stockmann (1988) emphasizes the importance of sectoral shocks for business cycles. He states that two countries will be hurt similarly by sector-specific shocks if they have economic sectors of similar nature and size. In other words, he considers that the more similar the economies, the more correlated their cycles.

However, for Imbs (2004), specialization patterns play an independent role in cycle correlation which renders the evidence regarding the economic specialization effect ambiguous.

Kalemli-Ozcan et al. (2001) argue that countries with a high degree of financial integration tend to have more specialized industrial patterns and less synchronized business cycles. They consider that, with higher integration in both international financial markets and goods markets, countries should be able to insure against asymmetric shocks through diversification of ownership and can afford to have a specialized production structure. In this case, better opportunities for income diversification induce higher specialization in production, which are associated with more asymmetric business cycles.

However, evidence from the financial crises and contagion literature indicates a direct positive effect of capital flows to business cycle synchronization. In this frame, Kose et al. (2003) point out that financial integration enhances international spillovers of macroeconomic fluctuations leading to more business cycle synchronization.

\footnotetext{
${ }^{6}$ WAEMU is the West African Economic and Monetary Union and ECCAS is the Economic Community of Central African States.
} 


\section{Empirical Methodology and Data}

\section{A. Variables and data}

Our empirical analysis refers to the Frankel and Rose (1998) endogeneity hypothesis and relies on measures of two key variables: correlation of business cycles and bilateral trade intensity.

The correlation of business cycles in the Maghreb countries is computed after detrending the annual real GDP series using both Hodrick-Prescott (HP) and Band Pass (BP) filters. ${ }^{7}$ It is calculated by computing the correlation coefficient between the cycles of pair countries. In addition, we privileged here a five years' moving correlation ${ }^{8}$ for detrended bilateral real GDP instead of a static one. ${ }^{9}$ Data for real GDP were extracted from the Chelem Database of CEPII.

As for trade intensity, it is constructed by reporting bilateral trade to the total trade: ${ }^{10}$

$$
\operatorname{Trade}(i, j) t=\frac{\left(X_{i j t}+M_{i j t}\right)}{\left(X_{i t}+X_{j t}+M_{i t}+M_{j t}\right)}
$$

where $M_{i j}$ denotes total nominal exports from country $i$ to country $M, M_{i j}$ denotes total nominal imports from country $i$ to country $j, X_{i t}$ denotes total global exports from country $i$, and $M_{i t}$ denotes global imports of country $i$. We also use a five years' moving average for this variable. The data were extracted from the CD-ROM of Direction of Trade Statistics of IMF.

In addition to the trade intensity, our extended regression includes a vector of control variables made up of intra-industry trade, similarity of economic structures, and financial integration indicators as shown in Table A.

For Intra-Industry Trade variable (IIT), it is measured using the nine commodity

\footnotetext{
${ }^{7}$ For the BP filter, we apply here the full length asymmetric filter of Christiano and Fitzgerald (2003).

${ }^{8}$ The usefulness of this correlation is twofold: capturing some dynamics in the co-movement and allowing gains of many observations.

${ }^{9}$ Note that other proxies can be used in order to compute the correlation of real activity such as industrial production, total employment, and the unemployment rate. Shortness of data for Maghreb countries prevents us from using these indicators.

${ }^{10}$ Another measure of trade intensity can be stated where bilateral trade is normalized by nominal GDP in two countries instead of total trade.
} 
products $^{11}$ defined in the Chelem Database and is constructed according to the GrubelLloyd index: ${ }^{12}$

$$
I I T_{i j}=\frac{\sum_{k=1}^{9}\left(X_{i j k}+M_{i j k}\right)-\left|X_{i j k}-M_{i j k}\right|}{\sum_{k=1}^{9}\left(X_{i j k}+M_{i j k}\right)}=1-\frac{\sum_{k=1}^{9}\left|X_{i j k}-M_{i j k}\right|}{\sum_{k=1}^{9}\left(X_{i j k}+M_{i j k}\right)}
$$

where $X_{i j k}$ and $M_{i j k}$ denote exports and imports of commodity product $k$. It follows that an index of 0 represents a complete specialization in different products for each country; whereas an index of 1 means that all trade is intra-branch $\left(M_{i j k}\right.$ equals $\left.M_{i j k}\right)$.

With regard to the similarity of economic structure indicator $\left(E S_{i j}\right)$, we look at the composition of each sectoral value-added share of GDP between pairs of countries. Using the three main sectors of agriculture, industry, and services, we construct this indicator according to the Krugman (1991) index: ${ }^{13}$

$$
E S_{i j}=\sum_{p=1}^{3}\left|S_{i p}-S_{j p}\right|
$$

where $S_{i p}$ and $S_{j p}$ stand for the value-added share of sector $p$ in country $i$ 's and $j$ 's aggregate GDP, respectively. It stands that the higher the value of this indicator, the greater the difference in industry shares between countries $i$ and $j$ and, therefore, the lower the similarity in structures of production. Data for $S_{i p}$ and $S_{j p}$ were extracted from the World Development Indicator (WDI) database (2010).

Finally, concerning the financial integration variable $\left(F I_{i j}\right)$, it is computed according to $\mathrm{Ng}$ (2010) where, for each country-pair, we sum a pair-wise individual Chinn and Ito (2008) actualized index. ${ }^{14}$

\footnotetext{
${ }^{11}$ These products are: building materials, steel, textile, mechanics, chemicals, ores, energy, agriculture, and food products.

${ }^{12}$ Mauritania is excluded here because of a lack of data.

${ }^{13}$ Libya is excluded given the absence of data

${ }^{14}$ This index refers to the four measures of capital flows restrictions reported in the IMF's Annual Report on Exchange Arrangements and Exchange Restrictions (AREAER): (i) presence of multiple exchange rates, (ii) restrictions on current account transactions, (iii) restrictions on capital account transactions, and (iv) requirement of surrender of export proceeds. The index of capital account openness is created by computing the first standardized principal component of these four measures.
} 
Notice that, for these three latter variables, as in the case of cyclical component of real GDP and trade intensity variables, we use a five years' moving average in order to be compatible with the regression framework.

\section{B. Estimation techniques}

As stated above, our aim here is to test the effect of trade intensity on the correlation of business cycles for the Maghreb countries, based on the Frankel and Rose (1998) endogeneity hypothesis over the period 1980 2010. We estimate the following panel regression:

$$
\operatorname{Corr}(i, j) t=\alpha+\beta \operatorname{Trade}(i, j) t+\varepsilon(i, j) t
$$

where Corr $(i, j) t$ is the degree of correlation of economic activity between countries $i$ and $j$ over period $t$; Trade $(i, j) t$ is the measure of bilateral trade intensity over period $t$ and $\varepsilon(i, j) t$ are factors other than trade which influence the correlation degree during period $t$.

Our coefficient of interest is $\beta$. We concentrate on its sign and magnitude: if it is positive, trade intensity increases business cycle synchronization, i.e., OCA effect dominates and the Frankel and Rose hypothesis is valid, whereas if it is negative, it causes desynchronization of business cycles, i.e., specialization hypothesis prevails and the Frankel and Rose hypothesis is not valid. However, if it is high, trade impact on business cycle synchronization is important and vice versa.

But, given that this basic relation omits many other variables that would explain the evolution of business cycles correlation, we check the robustness of this relationship by adding control variables. Therefore, our extended equation is as follows:

$$
\begin{aligned}
\operatorname{Corr}(i, j) t & =\alpha+\beta_{1} \operatorname{Trade}(i, j) t+\beta_{2} I I T(i, j) t \\
& +\beta_{3} E S(i, j) t+\beta_{3} F I(i, j) t+\gamma Z(i, j) t+\varepsilon(i, j) t
\end{aligned}
$$

where IIT $(i, j) t$ represents intra-industry trade variable, $E S(i, j) t$ is the indicator of the similarity of economic structure, $F I(i, j) t$ represents financial integration variable, Trade $(i, j) t$ represents the same variables as in Equation (4), while $Z(i, j) t$ is the vector of control variables over period $t$, that are described in Table A. 
We use three different techniques to estimate Equations (4) and (5). The first one is pooled OLS estimate. This estimation is especially useful when the groups to be pooled are relatively similar or homogenous ${ }^{15}$ which may be the case for the Maghreb countries.

However, when there are strong reasons to suppose heterogeneity between a pair of countries, the fixed and random effects estimation techniques can be very useful. For example, the divergence in terms of economic structure and institutional framework between Algeria and Libya on the one hand and Morocco, Tunisia, and to a lesser extent, Mauritania on the other hand, can justify the use of these techniques. So, including country pair fixed effects allows us to control for all the time-invariant, country pairspecific variables which may have an impact on output correlation. ${ }^{16}$ The choice between fixed effects versus random effects model is performed via Hausman test.

Finally, we employ the 2SLS technique to estimate our equations. Generally, recourse to this technique is explained by the fact that the OLS may be out of place, since the increase of bilateral trade intensity may be the result of a stronger correlation of business cycles.

To deal with this problem of the endogeneity bias, we use the Instrumental Variable (IV) technique by drawing from the gravity model of trade. The instruments chosen from this model suppose that they are correlated with trade intensity, but can reasonably be unaffected by other conditions which alter the co-movements of business cycles in Maghreb countries.

Basically, we often find countries that share a common border, closer in distance, have trading partners that are farther away from the rest of the world, members of the same region, speak the same language, have the same colonial origin, have the same common main trading partner, have higher population, and engage in regional free trade agreements, trade more intensively (Calderón et al. 2007).

In our work, to get valid instruments and consistent estimation, we proceed in the following way. First, we run an OLS estimation of the gravity model for Maghreb countries and retain the significant variables or instruments. ${ }^{18}$ Then, we run many 2SLS estimations by using two approaches: Kleibergen-Paap's (2006) approach that tests the weakness of the instruments and Hansen's (1982) approach which performs the

\footnotetext{
${ }^{15}$ Econometrically, this hypothesis implies that the parameters of the model are homogeneous for all country pairs.

${ }^{16}$ Note that the results coming from the first two estimation techniques should be considered with caution since there is an endogeneity bias which we control later by using 2SLS.

${ }^{17}$ For more details, see Table A.

${ }^{18}$ The results are available upon request.
} 
exogeneity of these instruments. We finally retain the 2SLS estimation that contains the most valid instruments. ${ }^{19}$

\section{Estimation Results}

Before stating our results, we present some main descriptive statistics for the key variables outlined in Table B. From this table, we note much more variability for the dependent variables than the regressors except the financial integration indicator. In fact, bilateral GDP correlation has variability with a range between -0.93 to 0.99 using HP filter and -0.96 to 0.96 using the BP one while bilateral trade intensity has less variability with a range between 0 and 0.02 . Also, intra-industry trade and similarity of economic structure indicators have variability with a range between 0.001 to 0.5 and 0 to 1 , respectively.

Moreover, the dependant variables have a larger standard deviation than the independent ones except for the financial integration variable. Indeed, it is about 0.5 for GDP correlation and 0.6 for financial integration while it is about $0.003,0.14$, and 0.21 , respectively, for bilateral trade intensity, intra-industry trade, and similarity of economic structure.

\section{A. Trade intensity and correlation of business cycles}

Table C summarizes the effect of trade intensity on the correlation of business cycles in Maghreb countries from Equation (4). The Hausman test suggests that a random effects model is more suitable than a fixed effects one. Moreover, under-identification as well as over-identification tests confirm the validity of our instruments and the relevance of the 2SLS regressions.

This shows first that our coefficient of interest $\beta$ is positive and significant, suggesting that bilateral trade intensity generates synchronized business cycles. Such a result is robust to changes in the de-trending technique used to compute the cyclical

\footnotetext{
${ }^{19}$ Among the instruments, common colonizer, distance, and common borders are valid as it can be seen from Table A.
} 
fluctuations of output. Indeed, an increase of one standard deviation in bilateral trade intensity raises the output correlation from 0.04 to 0.06 using the HP filter and from 0.05 to 0.09 using the BP filter. ${ }^{20}$ Probably, the progress of these countries toward trade liberalization and the signing of many bilateral agreements such as Agadir Agreement, Greater Arab Free Trade Agreement, may explain the role of increasing trade in the synchronization of business cycles. Moreover, high trade intensity with European partners seems to be a catalyst for this harmonization process in these countries; for instance, more than $50 \%$ of Algerian, Libyan, Moroccan, and Tunisian exports and imports are to and from the European Union.

However, from the same Table, we can note that the magnitude of this effect in Maghreb countries is smaller compared to the results found in existing literature for industrial countries. In fact, Frankel and Rose (1998) as well as Calderón et al. (2007) found that an increase in bilateral trade intensity by one standard deviation leads to an increase in business cycle correlation from 0.22 to 0.35 and from 0.25 to 0.39 , respectively

There are many explanations for this result. On the one hand, in Maghreb countries, patterns of specialization prompt us to expect a small correlation between trade integration and business cycle correlation. The reason is that, contrary to other regional blocs, there is a lower volume of trade between them as it can be seen from Figure 1. Indeed, even though Algeria and Libya are net oil-exporters whereas Tunisia, Mauritania, and Morocco are net oil-importers, economic and especially political problems continue to hinder the exchange of goods and services. Absence of modern infrastructure, shortness of a common trade vision, importance of non-tariff barriers, as well as border conflicts are often invoked as real barriers to trade.

On the other hand, the import and export preferences of these countries push them to be rather anchored to European markets. Algeria and Libya, like many other resourceabundant countries, have a very small share of non oil-exports while Tunisia, Mauritania, and Morocco display greater trade openness but have been import biased. However, the exports of non-oil exporting countries have been increasingly falling short of imports, implying increasing trade balance deficits (World Bank 2006).

As we have already pointed out, trade is probably not sufficient in itself to explain the dynamic correlation of business cycles between two or more countries. So, adding other variables in the model allows us to improve the quality of regression and to check the

\footnotetext{
${ }^{20}$ The final correlation reported in this paper is equal to the product of one standard deviation of trade intensity and its coefficient estimate. For example, for pooled regression, the final correlation is equal to $15.384 * 0.003$ (for HP filter) and $19.551 * 0.003$ (for BP filter).
} 
robustness of the aforementioned results.

\section{B. Robustness analysis}

Table D states the effect of trade intensity (inter-industry and intra-industry trade) as well as control variables on the correlation of business cycles in Maghreb countries from Equation (5). It shows that the small effect of bilateral trade intensity on co-movements of business cycles is always present suggesting that our results are robust. Indeed, an increase of one standard deviation in bilateral trade intensity raises the output correlation from 0.04 to 0.07 using the HP filter and from 0.05 to 0.09 using the BP filter. However, the intra-industry trade variable do not matter for business cycle co-movements in Maghreb countries since $\beta_{2}$ is not significant. This is probably due to the absence of any fragmentation in the production process. In fact, most of the intra-industry traded goods are substitutes and not complements since the main merchandise exports of these countries are labor-intensive that do not contain important spendings on research and development, and lack workforce qualifications.

On the other hand, quasi-complete specialization and the resulting weakness of intraindustry trade in these countries could also explain this result. Maghreb countries are in fact more specialized in trading one type of product such as energy in Algeria and Libya, textiles, agriculture, and food products in Morocco, and chemicals and mechanical products in Tunisia. Besides, the Grubel-Lloyd index has been very low compared to other regional blocs as it can be seen from Figure 2.

As for the economic structure variable, the expected negative relationship with the cycle correlation is not confirmed but the interaction between the two variables is almost absent. Indeed, an increase of one standard deviation of the Krugman index causes a very small increase of the output correlation using both filters. This result could probably be ascribed to the fact that the economic structure of these economies is not so divergent. In fact, taken as a whole, the Maghreb region's growth depends heavily on foodstuffs, semi-finished products, and consumer goods, except for Algeria.

However, as regards the financial integration variable, we observe a positive relationship between this variable and business cycles co-movements. Indeed, according to our results, an increase of one standard deviation in the bilateral financial openness index causes an increase of the output correlation from 0.15 to 0.16 using the HP filter and from 0.11 to 0.12 using the BP filter. This result is consistent with the research 
of Kose et al. (2003) where financial integration enhances international spillovers of macroeconomic fluctuations and leads to more business cycle correlation. Then, the actions taken by the authorities of Maghreb countries, in term of capital transactions, foreign direct investments, and credit operations, ${ }^{21}$ seem to be catalysts for business cycles harmonization in these countries.

\section{Policy Implications}

This paper examines the effect of the current economic integration process, notably trade integration, on the correlation of business cycles in Maghreb countries, by testing the Frankel and Rose (1998) endogeneity hypothesis of Optimal Currency Area (OCA). Our main results suggest that trade intensity has positive effects on business cycles synchronization in these countries, but, at the same time, these effects are by far below those registered in industrial countries. Arguments linked to trade patterns and specialization issues are stated in this frame. Moreover, by introducing control variables, we prove that our primary results are robust since we do not find important interaction between trade and business cycles contrary to the case of industrial countries.

Finally, we prove that economic structure has a very small effect on the synchronization of business cycles while financial integration plays an important and positive role. It goes without saying that monetary integration between Maghreb countries is not an endogenous process and these countries have to make more efforts before creating a currency union.

In this sense, the following recommendations could be stated.

- Increasing trade linkage between Maghreb countries could be a very useful means of increasing business cycle correlation.

- These countries could anchor their currencies to the euro rather than adopting a unique currency. The reason for this is that an important share of Maghrebian trade is carried out with the European Union and such an importance could offer a better

\footnotetext{
${ }^{21}$ For an overview, see Tahari et al. (2007).

${ }^{22}$ For the effect of financial integration on co-movements of business cycles in Europe, see Adjaoute et al. (2003), Angeloni and Ehrmann (2003), and Perée and Riess (2003).
} 
allocation of resources and ensure business cycles synchronization between the two Mediterranean rims.

- Many steps towards a successful economic and monetary integration process in the long run could be done. In particular, production diversification as well as adoption of complementary economic policies such as liberalizing trade in services, increasing trade facilitation initiatives, and reinforcing the business climate, could improve trade diversification, boost the harmonization process in the region, and better resource allocation and sounder management in the expected currency area.

- Acceleration of the financial integration process and improving of the coordination of financial, monetary, and exchange rate policies between them could be very useful since it would reduce the uncertainty and improve efficiency gains.

Received 17 October 2013, Revised 9 February 2015, Accepted 22 July 2015

\section{References}

Adjaouté, K., Danthine, J.P. and Isakov, D. "Portfolio Diversification in Europe." FAME Research Paper N84(2003).

Angeloni I and Ehrmann M. "Monetary Transmission in the Euro Area: Early Evidence." Economic Policy, 18(2003), 37, 469-501.

Baldwin, R. "What Effect is EMU having on the Euro Area and its Member Countries?" The Euro's Trade Effects. Graduate Institute of International studies, Geneva. Presented at the June 2005 ECB conference (2005)

Bangaké, C. and Eggoh, J. "The Impact of Currency Unions on Trade: Lessons from CFA Franc Zone and Implications for Proposed African Monetary Unions." Savings and Development 33(2009), 1, 61-72.

Baxter, M. and Kouparitsas, M. "Determinants of Business Cycle Co-Movement: A Robust Analysis.” Journal of Monetary Economics 52(2005), 113-157.

Beine, M. L'Union Economique et Monétaire Européenne à la Lumière de la Théorie des Zones Monétaires Optimales : Une Revue de la Littérature, Mimeo, Université Lille 
II. (1998)

Calderón, C., Chong, A. and Stein, E. "Trade Intensity and Business Cycle Synchronization: Are Developing Countries any Different?’ Journal of International Economics 71(2007), $1,2-21$.

Caporale, G.M., De Santis, R. and Girardi, A. "Trade Intensity and Output Synchronisation: On the Endogeneity Properties of EMU." Journal of Financial Stability. .doi.org/10.1016/j.jfs.2014.01.003 (2015)

Carrère, C. "African Regional Agreements: Impact on Trade with or without Currency Unions." Journal of African Economies 13(2004), 2, 199-239.

Chinn, M. and Ito, H. "A New Measure of Financial Openness." Journal of Comparative Policy Analysis 10(2008), 3, 309-322.

Christiano, L. and Fitzgerald, T. "The Band Pass Filter." International Economic Review 44(2003), 2, 435-465.

Darrat, A.F. and Pennathur, A. "Are the Arab Maghreb Countries Really Integrable? Some Evidence from the Theory of Cointegrated Cystems." Review of Financial Economics 11(2002), 79-90.

Fidrmuc, J. "The Endogeneity of Optimum Currency Area Criteria, Intra-Industry Trade and EMU Enlargement.” Contemporary Economic Policy 22(2004), 1, 1-12.

Frankel, J. and Rose, A. "The Endogeneity of the Optimum Currency Area Criteria", Economic Journal 108(1998), 449, 1009-1025.

Gouveia, S. and Correia, L. "Trade Integration and Business Cycle Synchronization in the Euro Area: The Case of Southern European Countries." Journal of Economic Integration 28(2013), 1, 85-107.

Hansen, L-P. "Large Sample Properties of Generalized Method of Movements Estimators.” Econometrica 50(1982), 1029-1054.

Imbs, J. "Trade, Finance, Specialization, and Synchronization." Review of Economics and Statistics 86(2004), 3, 723-734.

Inklaara, R., Jong-A-Pina, R. and de Haan, J. "Trade and Business Cycle Synchronization in OECD Countries: A Re-examination.” European Economic Review 52(2008), 646-666. 
Kalemli-Ozcan, S., Sørensen, B.E. and Yosha, O. "Economic Integration, Industrial Specialization, and the Asymmetry of Macroeconomic Fluctuations." Journal of International Economics 55(2001), 107-137.

Kenen, P. "The Theory of Optimum Currency Areas: An Eclectic View”, in Monetary Problems of the International Economy, ed. Mundell R.A. and Swoboda A.K, The University of Chicago, 1969.

Kleibergen, F. and Paap, R. "Generalized Reduced Rank Tests Using the Singular Value Decomposition.” Journal of Econometrics, 13(2006), 1, 97-126.

Kose, A., Prasad, E., and Terrones, M. "How Does Globalization Affect the Synchronization of Business Cycles?" American Economic Review 93(2003), 57-62.

Krugman, P. Geography and Trade. The MIT Press, Cambridge, MA (1991)..

Krugman, P. "Lessons of Massachusetts for the EMU”, in Torres, F., Giavazzi, F. eds, Adjustment and Growth in the European Monetary Union. Cambridge University Press, 1993.

Kumakura, M. "Trade and business cycle co-movements in Asia-Pacific." Journal of Asian Economics 17(2006), 622-645.

Masson, P. and Patillo, C. The Monetary Geography of Africa. Brookings Institution Press, Washington D.C. (2004)

McKinnon, R. “Optimum Currency Areas.” American Economic Review 53(1963), 717725.

Mundell, R.A. "A Theory of Optimum Currency Areas." American Economic Review, 51(1961), 4, 657-665.

Natixis. Quelles Peuvent Etre les Causes d'une Homogénéité Croissante ou d'une Hétérogénéité Croissante des Pays dans une Union Monétaire, de la Similitude ou de la Divergence de plus en plus Grandes de leurs Cycles? Flash 2011-720, Septembre.

Ng, E.C.Y. "Production Fragmentation and Business-Cycle Co-Movements." Journal of International Economics 82(2010), 1-14.

Nitsch, V. "Comparing Apples and Oranges: the Effect of Multilateral Currency Unions on the Trade is Small. Mimeo", Berlin: Bankgesellschaft Berlin. (2002) 
Perée, E. and Riess, A. "The Transformation of Finance in Europe: Introduction and Overview." EIB papers 8(2003), 1, 11-34.

Rana, P. "Economic Integration and Synchronization of Business Cycles in East Asia." Journal of Asian Economics 18(2007), 711-725.

Rose, A. "One Money, One Market: Estimating the Effect of Common Currencies on Trade.” Economy Policy 17(2000), 7-46.

Shin, K. and Wang, Y. "Trade Integration and Business Cycle Co-movements: The Case of Korea with other Asian Countries." Japan and the World Economy 16(2004), 213230.

Stockman, A. "Sectoral and Aggregate National Disturbances to Industrial Output in Seven European Countries.” Journal of Monetary Economics 21(1988), 387-409.

Tahari, A., Brenner, P., De Vrijer, E., Moretti, M., Senhadji, A., Sensenbrenner, G. and Solé, J. "Financial Sector Reforms and Prospects for Financial Integration in Maghreb Countries.” IMF Working Papers 07/125(2007).

World Bank. "Is there a New Vision for Maghreb Economic Integration?" Social and Economic Development Group, MENA Region, November 2006. Document of the World Bank.

World Bank. World Development Indicators (WDI) on CD-ROM. Washington, DC(2010). 


\section{Appendices}

Table A. Data definitions and sources

\begin{tabular}{|c|c|c|}
\hline Variables & Definitions & Sources \\
\hline $\operatorname{Corr}(i, j) t$ & $\begin{array}{l}\text { Moving bilateral GDP correlation. Two filters are used for } \\
\text { de-trending GDP: the HP filter and the Band-Pass filter. }\end{array}$ & Chelem Database \\
\hline Trade $(i, j) t$ & Moving average of quotient bilateral trade/total trade & $\begin{array}{l}\text { Direction of Trade } \\
\text { Statistics of IMF }\end{array}$ \\
\hline $\operatorname{IIT}(i, j) t$ & Moving average of the Grubel-Lloyd index & Chelem Database \\
\hline$E S(i, j) t$ & $\begin{array}{l}\text { Moving average of the absolute value of the Krugman } \\
\text { (1991) index }\end{array}$ & WDI (2008) \\
\hline$F I(i, j) t$ & $\begin{array}{l}\text { Moving average of the pair-sum of the capital account } \\
\text { openness index }\end{array}$ & $\begin{array}{l}\text { Chinn \& Ito } \\
(2008)\end{array}$ \\
\hline \multicolumn{3}{|c|}{ Instrumental variables } \\
\hline GDP difference & Log of GDP difference in absolute value & Chelem Database \\
\hline GAFTA & $\begin{array}{l}\text { Dummy variable set equal to } 1 \text { if a pair of countries belong } \\
\text { to the Greater Arab Free Trade Area; } 0 \text { otherwise. }\end{array}$ & Chelem Database \\
\hline WTO & $\begin{array}{l}\text { Dummy variable set equal to } 1 \text { if a pair of countries } \\
\text { are members of the World Trade Organization; } 0 \text { otherwise. }\end{array}$ & Chelem Database \\
\hline$E U A$ & $\begin{array}{l}\text { Dummy variable set equal to } 1 \text { if a pair of countries } \\
\text { are signatories of European Union Agreement. }\end{array}$ & Chelem Database \\
\hline $\begin{array}{l}\text { Distance } \\
\text { border }\end{array}$ & $\begin{array}{l}\text { Log of the distance between capitals dummy variable: } \\
1 \text { if a pair of countries share a common border; } 0 \text { otherwise. }\end{array}$ & CEPII Database \\
\hline Border & $\begin{array}{l}\text { Dummy variable set equal to } 1 \text { for landlocked } \\
\text { countries; } 0 \text { otherwise. }\end{array}$ & CEPII Database \\
\hline Com-lang & $\begin{array}{l}\text { Dummy variable: } 1 \text { if a pair of countries share } \\
\text { a common language; } 0 \text { otherwise. }\end{array}$ & CEPII Database \\
\hline Com-col & $\begin{array}{l}\text { Dummy variable: } 1 \text { if a pair of countries share } \\
\text { a common colonizer; } 0 \text { otherwise. }\end{array}$ & CEPII Database \\
\hline Col-45 & $\begin{array}{l}\text { Dummy variable: } 1 \text { if a pair of countries had a colonial } \\
\text { relationship after } 1945 ; 0 \text { otherwise. }\end{array}$ & CEPII Database \\
\hline Cur-col & $\begin{array}{l}\text { Dummy variable: } 1 \text { if a pair of countries are } \\
\text { currently in a colonial relationship; } 0 \text { otherwise. }\end{array}$ & CEPII Database \\
\hline Smctry & $\begin{array}{l}\text { Dummy variable: } 1 \text { if a pair of countries were } \\
\text { the same country; } 0 \text { otherwise. }\end{array}$ & CEPII Database \\
\hline Comlang-ethno & $\begin{array}{l}\text { Dummy variable set to } 1 \text { if a language is spoken by } \\
\text { at least } 9 \% \text { of the population in both countries; } 0 \text { otherwise. }\end{array}$ & CEPII Database \\
\hline
\end{tabular}


Table B. Descriptive statistics for key variables

\begin{tabular}{|c|c|c|c|c|c|}
\hline & Obs. & Mean & Std. dev. & Min. & Max. \\
\hline Cor__HP & 260 & -0.047 & 0.498 & -0.937 & 0.995 \\
\hline Corr_BP & 260 & -0.017 & 0.517 & -0.966 & 0.968 \\
\hline Trade & 260 & 0.002 & 0.003 & 0 & 0.020 \\
\hline IIT & 132 & 0.210 & 0.140 & 0.001 & 0.504 \\
\hline ES & 132 & 0.475 & 0.216 & 0 & 1 \\
\hline FI & 260 & -2.307 & 0.618 & -3.662 & -0.172 \\
\hline
\end{tabular}

Figure 1. Maghreb intra-regional merchandise trade

(as \% of total merchandise trade)

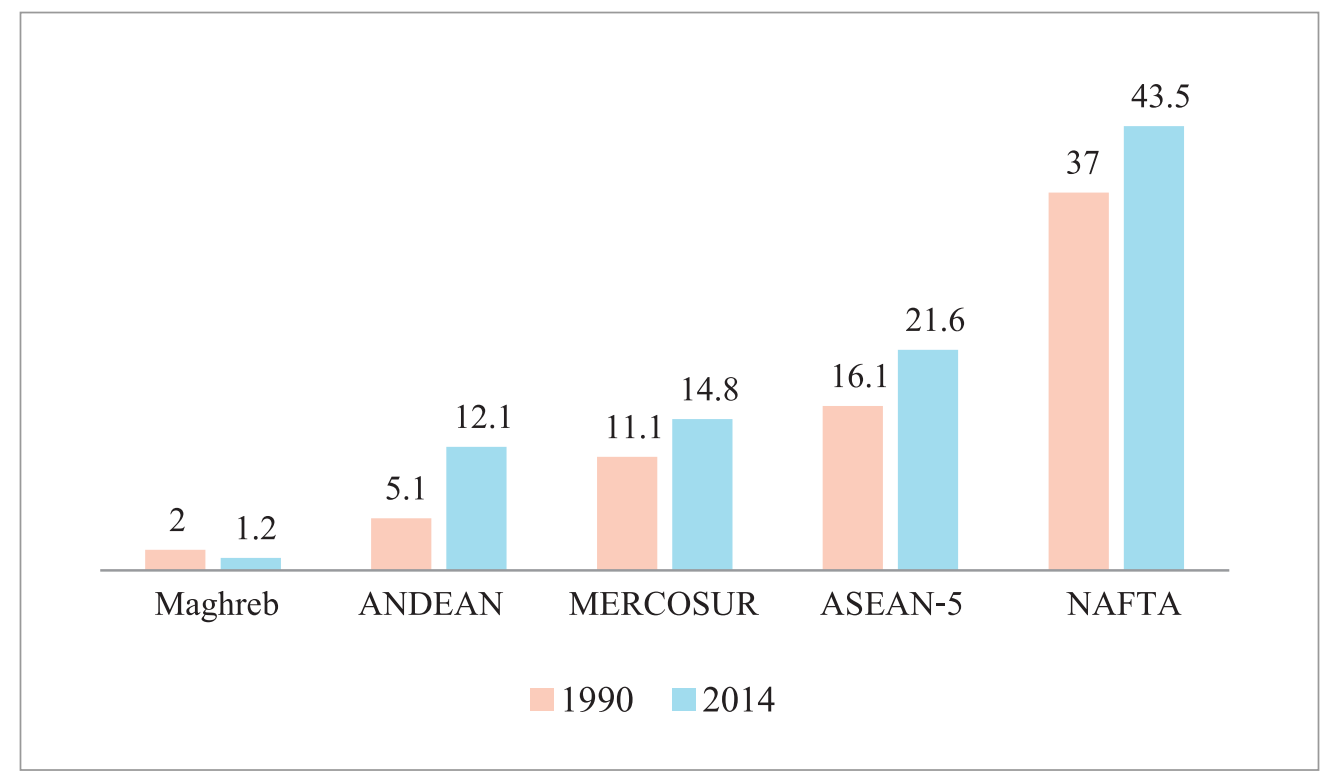

(Notes) ANDEAN = Bolivia, Colombia, Ecuador, and Peru; MERCOSUR = Argentina, Brazil, Paraguay, and Uruguay; ASEAN 5 = Malaysia, Thailand, Indonesia, the Philippines, and Singapore; NAFTA = United States, Canada, and Mexico.

(Source) World Bank (2006). 
Figure 2. Maghreb vs. comparators intra-industry trade

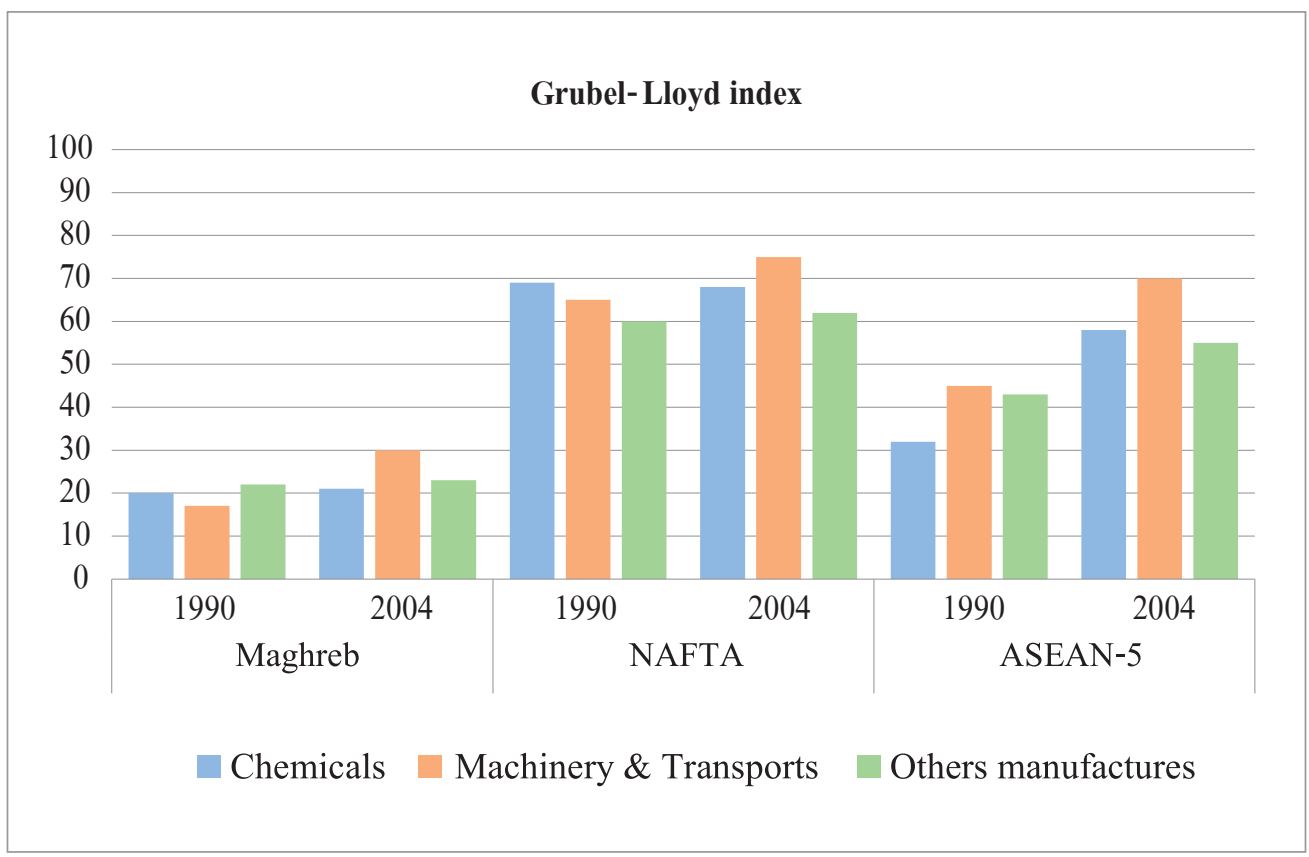

(Note) ASEAN 5 = Malaysia, Thailand, Indonesia, the Philippines, and Singapore; NAFTA = United States, Canada, and Mexico.

(Source) World Bank (2006). 


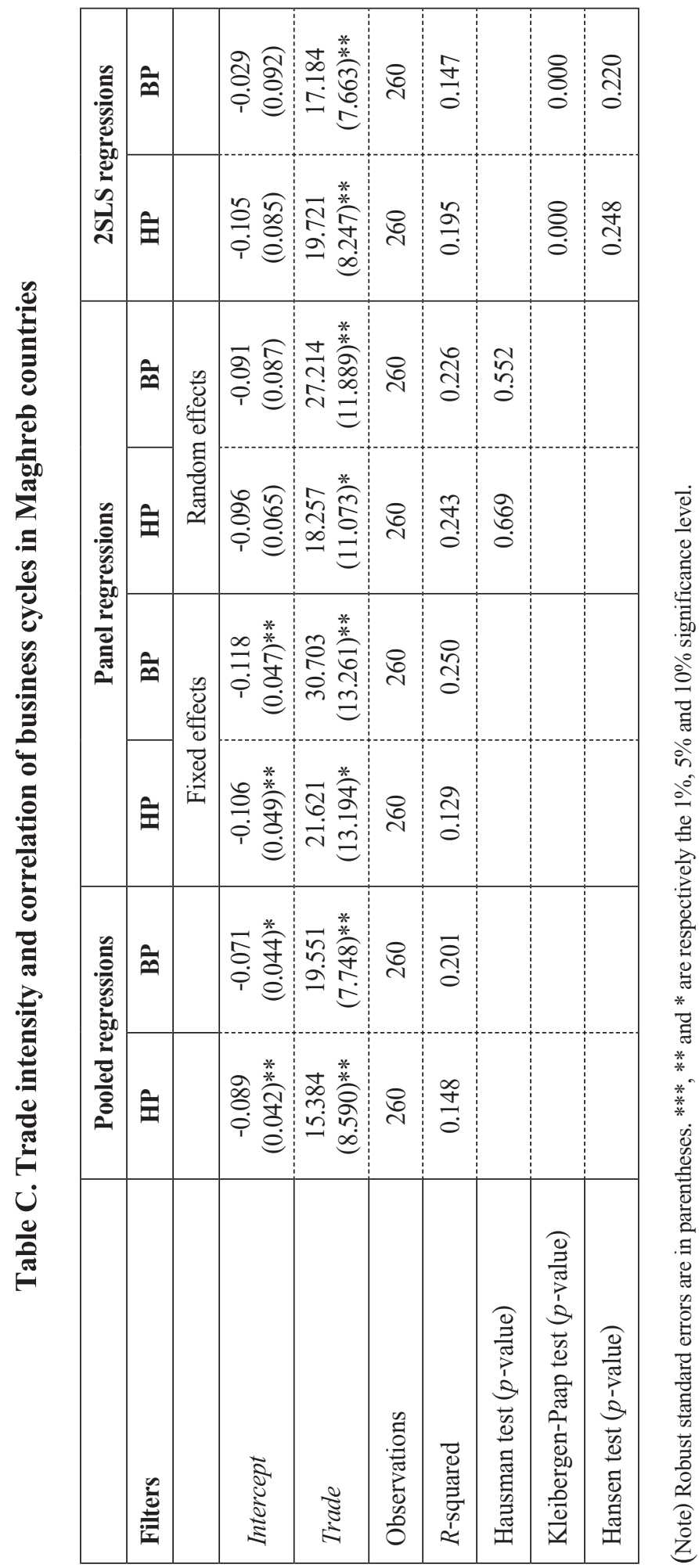




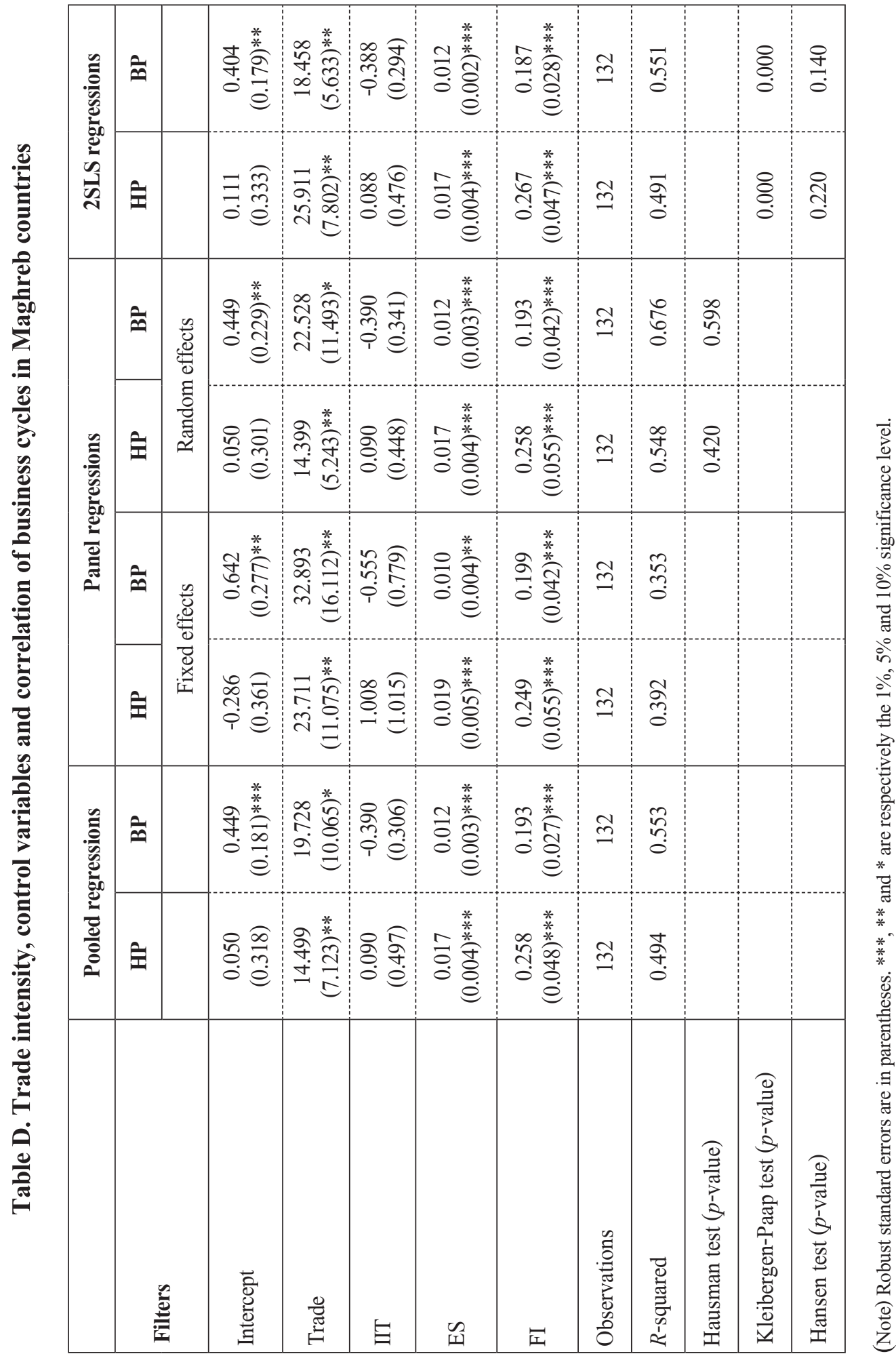

